Animal Health Research Institute In Assiut

\title{
ISOLATION AND SEROTYPING OF SALMONELLA SPECIES FROM RAW MILK OF COWS, BUFFALOES AND SHEEP IN ASSIUT GOVERNORATE
}

(With 2 Tables)

\author{
By \\ SOHAIR Z. HUSSEIN and EMAN KORASHY
}

(Received at 9/12/2007)

\section{عزل وتصنيف ميكروب السالمونيلا من اللبن الخام فى البقر والجاموس والغنم في محافظة أسيوط من لأني \\ سهير زين العابلين حسين ، إبيان قرشى}

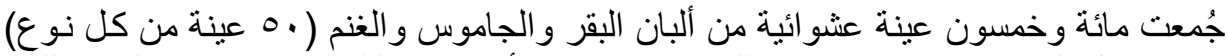

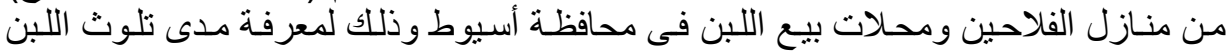

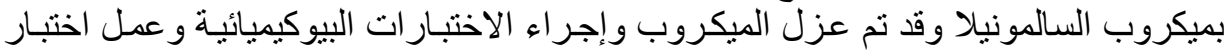

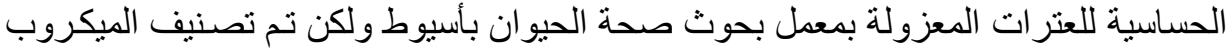

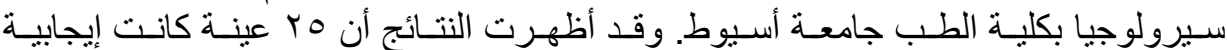

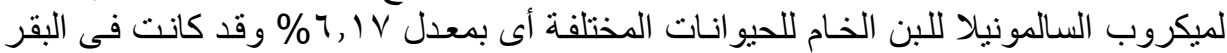

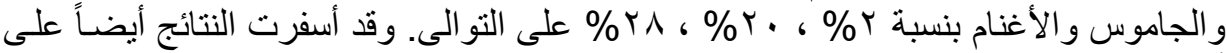

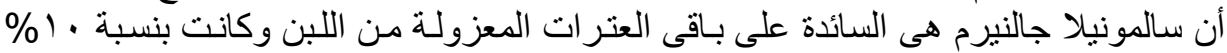

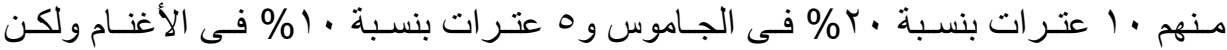

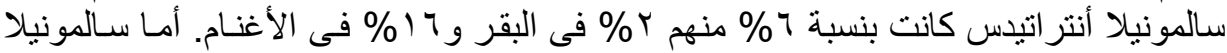

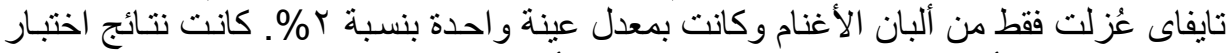

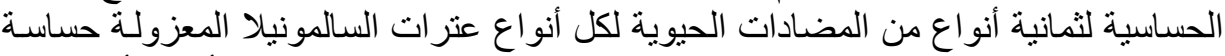

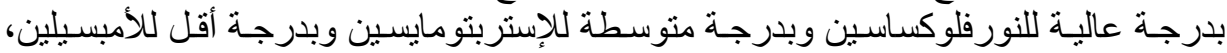

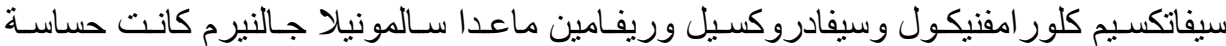
بدرجة منوسطة للجنتامسين وبدرجة أقل حساسية لكل من كلور امفنيكول وسيفادروكسيل.

\section{SUMMARY}

One hundred and fifty random samples of raw milk from cows, Buffaloes and Sheep (50 samples of each) were collected from different farmer's houses and dairy shops in Assiut Governorate to be examined for the presence of salmonella organisms on pre - enrichment and enrichment then plating on selective agar media, the Biochemical tests and serological tests were applied. The obtained results revealed that, the 
salmonella Spp. could be detected from raw milk of different animals were $25(6.17 \%)$ positive samples, $1(2 \%), 10(20 \%)$ and $14(28 \%)$ for cows, buffaloes and sheep milk, respectively. Serotyping of the isolated salmonella spp. revealed that, the Salmonella gallinarum was the most prevalent species among the salmonalla spp. 15 isolates (10\%) $10(20 \%)$ from buffaloes and $5(10 \%)$ from sheep. Salmonella enteritidis was isolated from 9 samples, 1 (2\%) from cows and 8 (16\%) from sheep but only one sample of sheep milk was positive for salmonella typhi. All types of the isolated salmonella were highly sensitive to Norofloxacin of the tested antiblotics and moderately sensitive to streptomycin and weekly sensitive to Gentamycin, Rifampin, Ampicillin, Cefotaxime, cefadroxil and chloramphenicol. However salmonella gallinerum was moderately sensitive to Gentamycin and resistant to Cefadroxil and Chloramphenical.

Key words:

\section{INTRODUCTION}

Salmonella is the most important food borne pathogen in the world. Food borne diarrheal diseases caused by salmonellae affect more than 300 million humans worldwide (Chevrier et al., 1995).

Salmonella is a leading cause of gastroenteritis in humans. Each year, approximately 40.000 cases of salmonelosis are reported in the united states, and it is estimated that 1.000 people die from acute salmonellosis (Anonymous, 2003). The majority of cases are due to the consumption of contaminated animal products such as poultry eggs, raw meats, raw milk and other dairy products that have not been pasteurized or have been handled inappropriately (Centers for Disease Control and Prevention, 1996. and 2000).

Milk and milk products have been identified as the vehicle for transmission in approximately 5\% of Salmonelosis cases, although the sources of infection remain unidentified in most cases (Centers for Disease Control and Prevention, 2000) Salmonellosis is commonly diagnosed in dairy cows and calves, and the presence of salmonella on dairy farms has been well documented, (losinqer, et al., 1995; wells, et al., 2001 and Huston et al., 2002a).

Salmonellosis in cattle can result in gastritis, abortion, decreased milk production or even death but fecal shedding of salmonella by asymptomatic animals has also been observed (Huston et al., 2002b). 
Although there is evidence of salmonella sheding by the mammary gland (Smith et al., 1989; Radke et al., 2002). Fecal contamination is also likely a major source of contamination of raw milk.

Rohrbach et al. (1992); Steele et al. (1997); Jayarao et al. (2001) and Murinda et al. (2002) reported that $0.17 \%$ of bulk tank milk was contaminated with salmonellae.

Kivanc, et al. (1992) detected salmonellae-shigella in two milk samples obtained from Eskishir markets. Wallaa (2004) detected salmonella (6\%) species in milk and some milk products in Assiut city, but Muehlherr, et al. (2003) and Ekici, et al. (2004) could not detecte salmonella spp. from cows, goats and ewes milk.

Although the majority of milk is consumed as pasteurized milk, many farmer familles drink raw milk (Jayarao, and Henning, 2001).

Soft Mexican - style cheeses are often made with unpasteurized milk, and several reported outbreaks of salmonellosis have resulted from the consumption of such chesses (Cody et al., 1999 and Villar et al., 1999).

\section{The purpose of this study:}

- Isolation and identification of salmonella Spp. from raw milk.

- Serotyping of the isolated salmonella Spp.

- Antimicrobial susceptibility of the isolated salmonella Spp. were done.

\section{MATERIALS and METHODS}

\section{1- Collection of samples:}

One hundred and fifty samples of raw milk from cows, buffaloes and sheep (50 samples of each). All samples were collected from Assiut city in clean, dry and sterile containers. Collected samples were transferred to the laboratory as soon as possible to be examined.

\section{2- Prepration of samples:}

Every milk sample was tested for detection of heat treatment by storch test according to Lampert, 1975.

\section{3- Methods of isolation of salmonella species:}

The methods of isolation used in this study were according to Andrews and Hammack, 2001 and involved four basic steps: Preenrichment, selective enrichment, selective plating and biochemical testing. 


\section{4- Serological identification:}

Serological identification by using the slide agglutination technique with polyvalent somatic $\mathrm{D}$ and $\mathrm{H}$ tests. The applied technique was recommended by Edwards and Ewing (1972) and International Commission on Microbiological Specification for Foods (1978).

\section{5- Antibiotics sensitivity test:}

The applied method and inhibitors zones were measured and recorded according to (Quinn, et al., 1994).

N.b. serotyping of isolated salmonella was performed by the department of bacteriology, Faculty of Medicine.

\section{RESULTS}

Table 1: Incidence of salmonella and salmonella serotypes from different raw milk samples

\begin{tabular}{|c|c|c|c|c|c|c|c|c|c|}
\hline \multirow{2}{*}{\multicolumn{2}{|c|}{$\begin{array}{c}\text { Examined } \\
\text { samples }\end{array}$}} & \multirow{2}{*}{\multicolumn{2}{|c|}{$\begin{array}{c}\text { No. of } \\
\text { positive } \\
\text { samples }\end{array}$}} & \multicolumn{6}{|c|}{ Salmonella serotypes } \\
\hline & & & & \multicolumn{2}{|c|}{ S. typhi } & \multicolumn{2}{|c|}{ S.enteritldis } & \multicolumn{2}{|c|}{ S. gallinarum } \\
\hline & No. & No. & $\%$ & No. & $\%$ & No. & $\%$ & No. & $\%$ \\
\hline Cows & 50 & 1 & $2 \%$ & - & - & 1 & $2 \%$ & - & - \\
\hline Buffaloes & 50 & 10 & $20 \%$ & - & - & - & - & 10 & $20 \%$ \\
\hline Sheeps & 50 & 14 & $28 \%$ & 1 & $2 \%$ & 8 & $16 \%$ & 5 & $10 \%$ \\
\hline Total & 150 & 25 & $16.7 \%$ & 1 & $0.7 \%$ & 9 & $6 \%$ & 15 & $10 \%$ \\
\hline
\end{tabular}

Table 2: Sensitivity test of the isolated salmonella serotypes.

\begin{tabular}{|l|c|c|c|}
\hline \multicolumn{1}{|c|}{ Antibiotics } & S. typhi & S. enteritidis & S. gallinarum \\
\hline 1- Norafloxacin $(\mathrm{NOR})_{10}$ & +++ & +++ & +++ \\
\hline 2- Chloramphenicol $\left(\mathrm{C}_{30}\right)$ & + & + & - \\
\hline 3- CEfadroxil $(\mathrm{CFR})_{30}$ & + & + & - \\
\hline 4- Ampicillin $(\mathrm{AM})_{10}$ & + & + & + \\
\hline 5- Rifampin $(\mathrm{RA})_{5}$ & + & + & + \\
\hline 6- Gentamycin $(\mathrm{CN})_{10}$ & + & + & ++ \\
\hline 7- Tetracycline $(\mathrm{TC})_{30}$ & + & + & + \\
\hline 8- Streptomycin $\left(\mathrm{S}_{10}\right)$ & ++ & ++ & ++ \\
\hline 9- Cefotaxime $(\mathrm{CTX})$ & + & + & + \\
\hline
\end{tabular}

N.b.
$(-)=$ Resistant
$(+)=$ weak sensitive
$(++) \quad=$ Moderately sensitive
$(+++)=$ highly sensitive 


\section{DISCUSSION}

Salmonella in dairy farms has been well documented (Huston et al., 2002). Milk and milk products have been identified as the vehicle for transmission in approximately 5\% of salmonellosis cases (Centers for Disease control and Prevention 2000).

The summarized data in Table. 1 show that the genus salmonella could be isolated with varying percentages from raw milk samples of cows, buffaloes and sheep in a percentage of 20,2 and 28\% respectively. Raw milk samples of sheep constitute the highest rate of contamination 28\%. (2\%) salmonella typhi, $16 \%$ salmonella enteritidis and $10 \%$ salmonella gallinarum. This may be related to the more relaxed microbiological standards for the production and distribution of sheep's milk than those of cow's milk which has stringent hygiene and quality regulations.

Salmonella gains acess to sheep's milk either by fecal contamination or by direct excretion from the udder into milk (Rampling 1996). Sheep's milk play an important role in transmitting more pathogens including food poisoning micro organisms due to consumption of raw milk (Foster et al., 1983). So, dairy industries for sheep's become important elsewhere (Maxy, 1993). Scanty data till now obtained concerning sheep's milk according to diary base line studies.

The present study in Table (1) also shows that the incidence of salmonella isolated from raw buffaloe's milk was $20 \%$ and the result was higher than that obtained by Singh and Singh (1966), Rohrbach et al., (1992) and Wallaa (2004); nearly to El Said, (2002). While, the results were in agreement with Sharma et al., (1995) who failed to detect salmonella in raw milk. High incidence of salmonella in raw buffaloe's milk came in line with Snyder and Poland, (1990) who postulated that high amount of fat in food provides a protective barrier around the microbial cells and prevent their disintegration by stomach during ingestion. Table (1) also reveals low incidence of salmonella isolated from raw cows milk samples $(2 \%)$. The results came in line with McEwen et al. (1988), lower than Wallaa, (2004) and higher than O'Donnell, (1995) and Steele et al. (1997).

Although Cullor, (1997) stated that salmonellae all widespread in the environment of dairy cows and their eradication is difficult. Raw buffaloe's and cow's milk may be contaminated by salmonella from the use of polluted water, dairy equipments and healthy dairy carriers. In addition, the organism may be eliminated with feces of workmen on the 
farm and secreted in milk of buffaloes and cows during the febrile stage of clinical salmonellosis. Rampling (1996). As shown in Table (1) salmonella species could be identified was salmonella enteritidis from raw cow's milk (2\%). The results came in hormoney with Anuszl (1980), WHO (1995) and Olsen et al. (2000) and Wallaa (2004) who recorded that salmonella enteritidis was a causative agent and it was responsible for $55 \%$ of food - borne disease outbreaks. Another species which is salmonella gallinarum that could be isolated from buffaloes's milk (20\%), salmonella gallinarum usually produces no or very milk infection (NRC 1969).

The differences in prevalence of salmonella among herds might have been caused by differences in hygiene and management practices by different media used (International standard organization "ISO" 1993).

Table (2) concerning the antimicrobial susceptibility pointed out that Norfloxacen $\left(\mathrm{NOR}_{10}\right)$ is the most predominant antibiotic was sensitive by all salmonella serotypes isolated from cows, buffaloes and sheeps milk samples.

While, the isolates were moderately sensitive to streptomycin $\left(\mathrm{S}_{10}\right)$ as reported by Farid (1976) and in contrast to Sojka and Hudson (1976). At the same time the isolates were weakly sensitive to Ampicillin $\left(\mathrm{AM}_{10}\right)$, Rifampin $\left(\mathrm{RA}_{5}\right)$ and Cefotaxime $\left(\mathrm{CT}_{30}\right)$ as reported by Sojka and Hudson (1976). Zein El Abden et al. (1966) stated that isolates from buffaloes were similar to those found in cattle. Results tabulated in Table (2) show that isolates that were initially identified biochemically as salmonella strains and subjected to serological identification were salmonella typhi (1) $2 \%$ from sheep's milk only, salmonella enteritidis (1) $2 \%$ and (8) $16 \%$ from cow's and sheep's milk samples, respectively. While, salmonella gallinarum was identified serologically from (10) $20 \%$ and (5) $10 \%$ of buffaloe's and sheep's samples respectively. Wallaa (2004) delt with serological identification of salmonellae.

In conclusion: The results obtained in this study reflect the importance of hygienic measures adopted during milking and handing by attendants to safeguard consumers from being infected by salmonellae to eliminate potentially of occurring hazard arizing from microbial contamination. 


\section{REFERENCES}

Andrews, W.H. and Hammack, T.S. (2001): Salmonella. In: Bacteriological Analytical Manual. $8^{\text {th }}$ Ed., Chapter 5.

Anonymous, (2003): Dupont qualicon BAX system adopted by USDA food safety and inspection service food prot. Trends 23: 492.

Anusz, Z. (1980): Salmonellosis in man and animal in plant in 19711978. medycyna veterynaryina. 36 (5): 265. Dairy Sci. Abst., 43: 976 (1981).

Centers for disease control and prevention (2000): Surveillance for foodborne - disease outbreaks - united states. 1993 - 1997. Morb. Mortal. WKLY. Rep. 49 (Surveillance summary - 1): $1-64$.

Centers for disease control and prevention. (1996): Surveillance for foodborne - disease outbreaks united states - 1988 - $1992-$ morb. Mortal - WKLY - Rep. 45 (Surveillance summary - 5): $1-66$.

Chevrier, D.; Popoff, M.Y.; and Dion, M.P. et al. (1995): Rapid detection of salmonella subspecies by PCR combined with non-radioactive hybridization using covalently immobilized oligomucleotide on amicroplate. FEMS immunol. Med. Microbiol. (10) 245 - 252.

Cody, S.H.; Abbott, S.L. and Marfin, A.A. et al. (1999): Two outbreaks of multidrug - Resistant salmonella serotype typhinurium DT 104 infections linked to raw - milk cheese in morthern California. J. Am. Med. Assoc. 281: 1805-1810.

Cullor, J.S. (1997): Risks and prevention of contamination of dairy products. Rev. Sci. Tech. Of. Int. Epiz., 16 (2): 472-481.

Edwards, P.R. and Ewing, W.A. (1972): Identification of Enterobacteriaceae. $2^{\text {nd }}$ Ed., Burges publishing company minneoplis 15, Minnesota.

Ekici, K.; Bozkurt, H. and Lsleyici, O. (2004): Isolation of some pathogens from raw milk of different Milch animals. Rakistan Journal of Nutrition (3): 161-162.

El-Said, E.I. (2002): Studies on food poisoning bacteria with special reference to campylobacter jejuni in milk. Ph.D. Thesis, Fac. Vet. Med., Zagazig Univ.

Farid, A.F. (1976): Isolation and antibiotic sensitivity testing of S.Kaapstad and S. Sofia from dead buffalo-cavels in Egypt. Proc. $13^{\text {th }}$ Arab Vet. Med. Cong., 11-20. 
Foster, G.M.; Nelson, F.E.; speck, M.L.; Doetch, R.N. and Olson, J.C. (1983): Dairy microbiology Ridgview Publ. Co., California.

Huston, C.L.; Wittum, T.E. and Love, B.C. (2002a): Persistent fecal salmonella shedding in five dairy herds. J. Am. Vet. Med. Assoc. 220: 650-655.

Huston, C.L.; Wittum, T.E.; Love, B.C. and Keen J.E. (2002b): Prevalence of fecal shedding of salmonella Spp. in dairy herds. J. Am. Vet Med. Assoc. 220: 645-649

International Commision on Microbiological specification for foods "ICMSF" (1978): Microorganisms in food, their significance and enumeration. $2^{\text {nd }}$ Ed., Univ. of Toronto a press Canada.

International Standard Organization "ISO" 6579 (1993): $3^{\text {rd }}$ ed., Microbiology-General guidance on methods for the detection of salmonella.

Jayarao, B.M., and Henning, D.R. (2001): Prevalence of food borne pathogens in bulk tank milk. J. dairy Sci: 84: 2157-2162.

Kivanc, M.; Kunduhoglu, B. and Agaz, B. (1992): Eskisehir'de tuketilem clg sutlerin bakteriyoljik kalitesinin halk sagligi yonunden incelenmesi. Gida, 17: 327-333.

Lampert, L.M. (1975): Modern dairy products $3^{\text {rd }}$ ed., chemical publishing company, Inc., New York.

Losinqer, W.C.; Wells, S.J.; Garber, L.P.; Hurd, H.S. and Thomass, L.A. (1995): Management factors related to salmonella shedding by dairy heifers. J. Dairy Sci. 78: 2464-2472.

Maxy, K. (1993): A year of progress dairy goat J. 11: 392.

McEwen, S.A.; Martin, S.W.; Clarke, R.C.; Tamblyn, S.E. and McDermott, J.J. (1988): The prevalence, incidence, geographical distribution, antimicrobial sensitivity patterns and plasmid profiles of milk filter salmonella isolates from Ontario dairy farms. Canadian J. Vet. Res. 52: 18:22.

Muehlherr, J.E.; Zweifel, C.; Blanco, J.E. and Stephan, R. (2003): Microbiological quality of raw goat's and ewe's bulk - tank milk in Switzerland. J. Dairy Sci. Dec., 86 (12): 3849-3856.

Murinda, S.E.; Nguyen, L.T. and Lvey, S.J. et al. (2002): Molecular characterization of salmonella Spp. isolated from bulk tank milk and cull dairy cow fecal samples. J. food prot. 65: 1100-1105.

NRC (1969): An evaluation of the Salmonella problem. National Academy of Sciences, Washington D.C. 
O'Donnell, E.T. (1995): The incidence of Salmonella and Listeria in raw milk from farm bulk milk tanks in England and Wales. J. Society of Dairy Technology, 48: 25-29.

Olsen, S.J.; Mackinon, L.C.; Goulding, J.S.; Bean, N.H. and Slutsker, L. (2000): Surveillance for foodborne Disease Outbreaks - united states, 1993 - 1997, MMWR: March 17, 2000.

Quinn, P.J.; Carter, M.E.; Markey and Carter, G.R. (1994): Clinical veterinary microbiology published by wolfe publishing an imprint of mosby book Europe Limited printed in Spain by Grofos, S.A Art sobrepapel.

Radke, B.R.; Mcfall, M. and Radostits, S.M. (2002): Salmonella muenster infection in dairy herd. Can. Vet. J. 43: 443-453.

Rampling, A. (1996): Raw milk cheeses and salmonella. British Medical J., 312: 67-68.

Rohrbach, B.W.; Drauughon, F.A.; Davidson, P.A. and Oliver, S.P. (1992): Prevalence of listeria monocytogenes. Campylobacter jejuni, yersinia enteroclitica and salmonella in bulk tank milk: Risk factors and Risk of human exposure J. food prot. 55: 93-97.

Sharma, V.D.; Dixit, V.P. and Joshi, R.K. (1995): Occurrence of salmonella serovars in foods of animal origin with special reference to antibiogram and enterotoxigenicity. J. Food Sci. Technol., 1995, 32 (3): 221-223.

Singh, R.S and Singh, I.P. (1966): Incidence of salmonella and shigella in samples of raw milk Ind. J. D. Sci., 19, 149-150.

Smith, B.F.; Oliver, D.G and Singh, P. et al. (1989): Detection of salmonella dullin mammary gland infection in carrier cows, using an enzyme - linked immunosorbent assay for antibody in milk or serum. Am. J. Vet. Res. 50: 1352-1360.

Snyder, O.P. and Poland. D.M. (1990): America's safe food Dairy food and environmental sanitation, 10 (12): 719-724.

Sojka, W.J. Wray, C. and Hudson, E.B. (1976): A survey of drug resistance in salmonella isolated from animals in England and Wales during 1973 - 1974. Br. Vet. J., 133. 292-305.

Steele, M.L.; Mcnab, W.B.; Poppe, C.; Griffiths, M.W. and Chen, S. (1997): Survey on Ontario bulk tank raw milk for food borne pathogens. J. Food Prot. 60 (11): 1341-1346.

Villar, R.G; Macek, M.D.; Simons, S. et al. (1999): Investigation of multidrug - resistant salmonella serotype typhinurium DT. 104 
infection linked to Raw - milk cheese in Washington state. J. Am Med. Assoc. (281) 1811-1816.

Wallaa, A.F.A. (2004): Some studies on salmonella species in milk and some milk products in Assiut city M. V. Sc. Assiut University, Egypt. .

Wells, S.J.; Fedorka-cary, P.J.; Dargatz, D.A.; Ferris, K. and Green, A. (2001): Fecal shedding of salmonella spp. by dairy cows on farm and at cull cow markets. J. food Prot. 64: 3-11.

World Health Organization "WHO" (1995): WHO surveillance program for control of food borne infections and intoxication in Europe. Sixth report $1990-1992,115-118$.

Zein-El-Abden, Y.; Mahmoud, A.H.; Awad, F.A. and El-Agroudi, M.A. (1966): Studies on salmonella infection in Egyptian buffalo. J. Vet. Sci., 3, 65-68. 